\title{
Perancangan Media Interaktif Escape Room Sebagai Media Promosi Pandora Experience di Surabaya
}

\author{
Edwin Hendrawan ${ }^{1 *}$, Baskoro Suryo Banindro ${ }^{2}$, Yusuf Hendra Yulianto ${ }^{3}$ \\ ${ }_{1,3}$ Program Studi Desain Komunikasi Visual, Fakultas Seni dan Desain \\ Universitas Kristen Petra, Jl. Siwalankerto No.121-131, Surabaya \\ ${ }^{2}$ Program Studi Desain Komunikasi Visual, Fakultas Seni Rupa, \\ Institut Seni Indonesia Yogyakarta, Jl. Parangtritis Km. 6.5, Yogyakarta \\ *Penulis korespondensi; E-mail: edw_hend@yahoo.com
}

\begin{abstract}
Abstrak
Pada kenyataannya wahana escape room merupakan sebuah hiburan yang kurang diminati oleh masyarakat, sehingga perusahaan Pandora Experience mengalami kesulitan dalam menggaet calon konsumennya. Kemajuan teknologi yang semakin canggih saat ini tidak menutup kemungkinan untuk membuat sesuatu yang unik, dalam hal ini adalah media interaktif berupa aplikasi yang beranama Unravel. Unravel merupakan aplikasi yang dapat diakses melalui device Android, dan penggunanya dapat berinteraksi dalam aplikasi tersebut. Untuk itu dengan membuat perancangan media interaktif escape room dapat menarik minat dari calon konsumen Pandora Experience, untuk mencoba wahana escape room.
\end{abstract}

Kata kunci: Aplikasi, Media Interaktif, Escape Room, Pandora Experience.

\begin{abstract}
Based on the facts, an escape room is an entertainment that is less attractive to the public. Thus, Pandora Experience company has difficulties in attracting prospective customers. The quick development of advanced technology does not rule out the possibility of creating something more unique, in this case, interactive media in the form of an application called Unravel. Unravel is an application that can be accessed through Android devices, and users can interact in the application. For that reason, by creating an escape room interactive media design, hopefully the interest of prospective Pandora Experience consumers to try out the escape room can be escalated.
\end{abstract}

Keywords: Application, Interactive Media, Escape Room, Pandora Experience.

\section{Pendahuluan}

Semakin berkembangnya industri kreatif dalam bidang entertainment di Indonesia, khususnya di Surabaya, yang memberikan keberagaman dalam dunia hiburan. Salah satu inovasi yang muncul adalah wahana permainan escape room yang dapat memberikan pengalaman yang berbeda bagimasyarakat. Pandora Experience merupakan salah satu industri yang mendirikan wahana escape room dengan menambahkan interaksi pemain dengan episodenya. Pandora memiliki beberapa cabang termasuk di Surabaya, tepatnya di Marvel City Mall, dan akan dibangun cabang baru yang terletak di Pakuwon Mall dan akan dibuka pada tanggal 14 Desember 2019.

Minimnya pengetahuan masyarakat mengenai wahana escape room Pandora Experience yang ada di Surabaya, yang disebabkan karena per- saingan dunia hiburan khususnya movie box yang lebih diminati oleh masyarakat sekarang dan masyarakat cenderung menikmati hiburan yang lebih umum dibandingkan Pandora Experience. Masalah ini terjadi karena kurangnya promosi yang dapat menjelaskan pengertian dari escape room itu sendiri, sehingga masyarakat hanya mengetahui tempat hiburan konvensional seperti; movie box, karaoke, café, taman hiburan, dan game center. Nyatanya sudah muncul 2 cabang escape room (Pandora Experience) di Surabaya, dengan jumlah pengunjung yang tidak stabil, dikarenakan lebih banyak customer lama yang datang dibanding dengan pendatang baru. Masalah ini yang membuat Pandora Experience juga mengalami sedikit kesulitan dikarenakan dari target market Pandora Experience yang merupakan $10 \%$ dari masyarakat Indonesia hanya berhasil mencapai $1.2 \%$ orang yang pernah bermain Pandora Experience 
(Timotius, 2019). Karena yang dialami oleh Pandora Experience sekarang adalah customer hanya bertanya mengenai apa itu escape room dan menanyakan harga, masyarakat tidak tertarik untuk mengeluarkan uang untuk bermain escape room. Sedangkan Pandora Experience sendiri merupakan sebuah wahana hiburanbaru yang ada di Surabaya dengan teknologi dan mekanisme permainan yang dapat memberikan interaksi dan pengalaman kepada pemain layaknya berada di sebuah film. Pandora Experience dapat memberikan pilihan hiburan kepada masyarakat yang sangat menyukai pengalaman baru dan hiburan yang interaktif, sehingga masyarakat memiliki pilihan hiburan yang tidak monoton. Oleh karena itu, perlu adanya media interaktif yang dapat memperkenalkan escape room secara tidak langsung melalui tutorial/demo yang dapat dimainkan oleh masyarakat, sehingga masyarakat dapat mengerti secara detail dengan mempraktekannya secara langsung di media interaktif escape room. Oleh karena itu, media interaktif dapat dijadikan sebagai media promosi yang dapat digunakan oleh masyarakat secara gratis dengan pengalaman dan interaksi yang hampir sama di dalam escape room. Media ini akan sangat efektif apabila ditempatkan pada Pandora Experience, karena Pandora Experience merupakan hiburan escape room yang sudah berjalan 5 tahun dan memiliki opportunity yang sangat besar untuk mengkampanyekan media interaktif ini melalui cabang barunya yang ada di Surabaya.

Pada perancangan ini, masalah yang ingin diselesaikan adalah Bagaimana merancang media interaktif escape room sebagai media promosi Pandora Experience di Surabaya. Karena pembuatan proyek media interaktif ini membutuhkan berbagai disiplin ilmu yang tidak semuanya dipelajari di mata kuliah desain grafis. Dalam perancangan sebuah media interaktif escape room, memiliki beberapa batasanbatasan masalah yang perlu diperhatikan, seperti:

1. Demografis, Target audiens adalah pria dan wanita berusia 20 - 25 tahun dalam kelas sosial menengah ke atas (A-B)

2. Geografis, Target audiens adalah pria dan wanita yang bertempat tinggal di jawa timur khususnya kota Surabaya.

3. Behaviour, Target audiens memiliki kebiasaan menyukai hal yang bersifat gratis, dan suka untuk mencoba hal baru khusunya dalam hal permainan, serta aktif dalam sosial media.

4. Psikografis, Target audiens memiliki gaya hidup yang sederhana dan mengikuti perkembangan zaman.
Tujuan dari perancangan media interaktif Escape room sebagai media promosi Pandora Experience di Surabaya diantaranya adalah merancang media interaktif escape room sebagai media promosi Pandora Experience di Surabaya.

Manfaat dari perancangan media interaktif escape room sebagai media promosi Pandora Experience di Surabaya diantaranya adalah memberikan hiburan pengalaman bermain escape room secara gratis, memberikan pengetahuan mengenai adanya industri kreatif berupa wahan escape room, mempromosikan industri kreatif baru yaitu Pandora Experience, mahasiswa dapat menambah wawasan dalam praktek dan teori-teori yang didapat selama perkuliahan untuk bekal diri menjadi graphic designer dan konseptor, serta mengaplikasikan salah satu bidang ilmu desain komunikasi visual secara nyata membantu menyelesaikan masalah yang ada dan menambah refrensi bagi mahasiswa desain komunikasi visual di Universitas Kristen Petra.

\section{Metode Pengumpulan Data}

Data-data yang dibutuhkan untuk menunjang perancangan ini dikelompokkan dalam beberapa jenis data yang diperoleh dengan berbagai macam cara yang berbeda, yaitu data primer dan data sekunder. Data primer adalah data yang diperoleh secara langsung dari obyek yang diteliti. Data primer akan diperoleh melalui metode wawancara dan observasi. Wawancara dilakukan secara mendalam untuk mengetahui informasi yang akurat untuk mendukung perancangan media interaktif ini.

Data sekunder (secondary data) adalah data yang diperoleh dalam bentuk yang tersedia melalui penelitian pustaka dan internet. Data yang diperoleh dapat berupa dokumen atau pun buku panduan cara bermain media interaktif, dan buku-buku cara membuat media interaktif.

\section{Tinjauan Pustaka}

\section{Pengertian Media}

Kata media berasal dari bahas latin Medius yang artinya sendiri adalah tengah, perantara, ataupengantar. Menurut Ahli Bahasa Syaiful Bahri Djamarah, media merupakan alat bantu apa saja yang dapat dijadikan sebagai penyalur pesan guna mencapai tujuan. Menurut 
Asociation of Education Comunication Technology (AECT) media merupakan segala bentuk dan saluran yang dipergunakan untuk proses penyaluran pesan. Menurut Ahli Teknologi Pendidikan Yusufhadi Miarso, media adalah segala sesuatu yang dapat digunakan untuk menyalurkan pesan yang dapat merangsang pikiran, perasaan, perhatian, dan kemauan siswa untuk belajar. Dari pengertian para ahli di atas, dapat disimpulkan bahwa media adalah saluran atau alat bantu yang berfungsi untuk penyalur informasi ataupun penyalur pesan. (Susilana \& Riyana, 2009)

Berdasarkan cara penggunaannya ada 3 jenis media komunikasi, yaitu: media komunikasi audial, media komunikasi visual, dan media komunikasi audio-visual.

1. Media Komunikasi Audial: Media ini merupakan alat komunikasi yang dapat didengar, ditangkap, dan dipahami oleh alat pendengaran.

2. Media Komunikasi Visual: media ini merupakan alat komunikasi yang dapat ditangkap, dilihat dan dipahami oleh alat penglihatan.

3. Media Komunikasi Audio-Visual: Media ini merupakan alat komunikasi yang dapat ditangkap, dilihat, didengar dan dipahami melalui alat pendengaran dan penglihatan.

\section{Media Interaktif}

Secara umum, media interaktif merupakan bagian dari media komunikasi. Menurut Kamus Besar Bahasa Indonesia, media interaktif bersifat saling melakukan aksi, antar-hubungan, saling aktif. Media interaktif dikatakan berhasil apabila konsumen dapat melakukan tindakan aktif dengan media yang disajikan.

Media interaktif dalam teknologi juga memiliki arti sebagai metode komunikasi di mana output program tergantung pada input pengguna, dan sebaliknya input pengguna dapat mempengaruhi output program. Sederhananya, hal ini mengacu pada berbagai cara di mana orang dapat memproses informasi dan berbagi informasi, atau bagaimana cara mereka bisa berkomunikasi satu sama lain. Media interaktif memungkinkan orang untuk terhubung dengan orang lain baik itu orang ataupun organisasi yang dapat menjadikan mereka peserta aktif dalam media yang mereka konsumsi (Dhir, 2019).

Menurut Daryanto, ajakan untuk ikut berpartisipasi aktif dapat dilakukan dengan cara meminta target untuk melakukan kegiatan menghitung, menulis, membaca, menirukan ucapan atau pelafalan, menjawab pertanyaan yang ditulis dalam buku catatan, mengamati lingkungan sekitar, membuat karangan singkat dan lain sebagainya.

Media Interaktif yang baik seharusnya dapat memunculkan komunikasi dua arah atau inter aktivitas antar dua orang. Pemilihan sebuah media interaktif juga harus disesuaikan dengan keperluan, dan harus sesuai dengan tujuan dari perancangan. Jika dilihat dari karakteristiknya media interaktif dibagi menjadi 2, yaitu media interaktif dua dimensi dan media interaktif tiga dimensi.

\section{Media Promosi}

Media sendiri dapat diartikan sebagai perantara ataupun pengantar pesan dari pengirim kepada penerima pesan. Secara harfiah "media" mempunyai arti perantara atau pengantar. Promosi adalah suatu bentuk komunikasi pemasaran. Komunikasi pemasaran adalah aktivitas pemasaran yang berusaha menyebarkan informasi, mempengaruhi atau mengingatkan pasar sasaran atas perusahaan dan produknya agar bersedia menerima, membeli, dan loyal pada produk yang ditawarkan oleh perusahan yang bersangkutan (Muqorobin, 2014).

Menurut para ahli diantaranya adalah, Zimmerer mengartikan promosi sebagai segala macam bentuk komunikasi persuasi yang dirancang untuk menginformasikan pelanggan tentang produk atau jasa dan untuk mempengaruhi mereka agar membeli barang atau jasa tersebut yang mencakup publistas, penjualan perorangan dan periklanan (Zimmerer \& Norman, 2008). Sedangkan menurut Saladin, promosi adalah salah satu unsur dalam bauran pemasaran perusahaan yang didaya gunakan untuk memberitahukan, mengingatkan, dan membujuk konsumen tentang produk perusahaan (Saladin, 2003).

Setiap perusahaan ingin meningkatkan penjualan produk ataupun jasa yang dapat ditawarkan dengan cara melakukan kegiatan promosi sebagai salah satu cara untuk meningkatkan penjualan ataupun pendapatan dari perusahaan itu sendiri. Perusahaan memiliki cara yang berbeda-beda untuk merancang promosi penjualan melalui mediamedia promosiyang dapat menjadi alat untuk menyebarkan informasi mengenai produk atau jasa yang dijual, dan juga mengenalkan profil 
ataupun nama perusahaan terhadap calon konsumen. Tujuan dari media promosi yang dibuat untuk memperoleh peningkatan profit, memperoleh pelanggan baru dan menjaga loyalitas konsumen, untuk menstabilkan penjualan, menunjukan karakteristik yang unik dari pesaing, membuat citra produk di mata konsumen agar sesuai dengan yang diinginkan, serta merubah tingkah laku dan anggapan konsumen terhadap produk yang ingin disampaikan.

\section{Iklan}

Iklan atau advertising dapat di definisikan sebagai "any paid form of nonpersonal communication about an organization, product, service, or idea by an identified sponsor" (setiap bentuk komunikasi nonpersonal mengenai suatu organisasi, produk, servis, atau ide yang dibayar oleh satu sponsor yang diketahui). Adapun maksud 'dibayar' pada definisi tersebut menunjukkan fakta bahwa ruang atau waktu bagi suatu pesan iklan pada umumnya harus dibeli. Maksud kata 'nonpersonal' berarti suatu iklan melibatkan media massa yang dapat mengirimkan pesan kepada sejumlah besar kelompok individu pada saat bersamaan (Morissan, 2010, p. 17).

\section{Advertorial}

Advertorial merupakan jenis iklan yang dikemas dalam gaya jurnalistik dan ditulis dalam bentuk editorial atau artikel yang memuat informasi mengenai kegiatan perusahaan atau review keunggulan sebuah produk disertai fakta empiris dan informasi yang berguna. Tujuan penulisan iklan ini adalah untuk menyatukan berita dan pesan komersil, sehingga menjadikan alat pemasaran ini bersifat lebih kredibel dan efektif. Advertorial dapat digunakan untuk melakukan promosi aktivitas perusahaan maupun promosi produk, yang pada dasarnya berusaha menggiring pembaca untuk menyakini bahwa perusahaan atau produk tersebut memberikan manfaat, serta menjadi solusi bagi permasalahan yang mereka hadapi (Sari, 2019). Dalam advertorial,terdapat dua fokus promosi yang bisa dikembangkan, yaitu:

1. Promosi aktivitas perusahaan, Hal ini dilakukan untuk menunjukkan intensitas perusahaan dalam menjalankan fungsi edukasi kepada masyarakat.

2. Promosi produk, seperti informasi mengenai kegunaan dari produk, sehingga masalah yang sering muncul di masyarakat dan teratasi berkat produk tersebut, atau masih banyak lagi. Secara langsung, iklan ini menggiring masyarakat untuk menganggap bahwa produk tersebut memang berkualitas, berkhasiat dan menjadi solusi terbaik (Maulina Rishna, 2019)

\section{Aplikasi}

Aplikasi adalah suatu perangkat lunak (software) atau program komputer yang beroperasi pada sistem tertentu yang diciptakan dan dikembangkan untuk melakukan perintah tertentu. Istilah aplikasi sendiri diambil dari bahasa Inggris "application" yang dapat diartikan sebagai penerapan atau penggunaan. Secara harfiah, aplikasi merupakan suatu penerapan perangkat lunak atau software yang dikembangkan untuk tujuan melakukan tugas-tugas tertentu.

\section{Android}

Android adalah sistem operasi untuk perangkat mobile berbasis Linux yang awalnya dikembangkan oleh Android Inc. Android terdiri dari system operasi, middleware, dan aplikasi. Android sendiri adalah sebuah sistem dalam bahasa inggris yang artinya adalah robot yang menyerupai manusia. Pada tahun 2005 Google secara resmi membeli Android. Sehingga pengembangan Android sepenuhnya berada di tangan Google.

\section{Data Perusahaan}

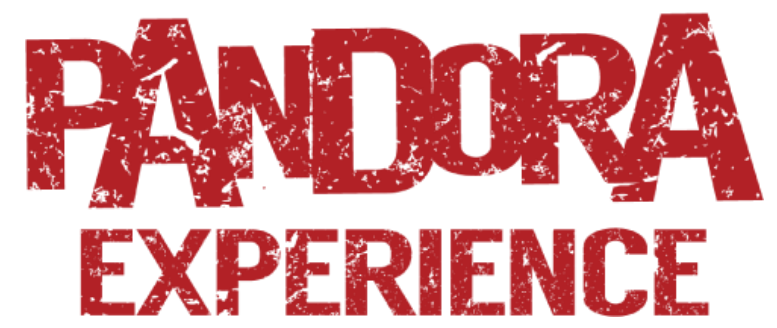

Gambar 1. Logo Pandora Experience

Nama Perusahaan : Pandora Experience Alamat : Jl. Mayjen Yono Suwoyo No.2, Babatan, Kec. Wiyung, Kota SBY, Jawa Timur 60227

Nomor Telepon : : 081946661213

Email : enquiry@pandoraexperience. com

Jam Buka

: $10.00-22.00$

Nama Pemilik : Michael Timotius dan Jancent Ong 
Pandora Experience adalah sebuah perusahaan yang bergerak di bidang industri kreatif, yang salah satu cabangnya bertempat di Surabaya tepatnya di Pakuwon Trade Center Supermall lantai 1. Pandora Experience bertujuan untuk memberikan hiburan dalam bentuk wahana escape room. escape room merupakan sebuah permainan petualangan meloloskan diri dari sebuah misteri dengan cara memasuki ruangan-ruangan permainan. Di sepanjang permainan yang memacu adrenalin ini, pemain akan menemukan kejutan-kejutan, lorong rahasia, ruangan rahasia, dan teka-teki yang membingungkan namun sangat seru.

Pandora Experience mendirikan cabang pertamanya pada tahun 2015 di Puri Indah, dan sekarang sudah memiliki 8 cabang di beberapa kota termasuk di Surabaya. Terbentuknya Pandora Experience berawal dari 2 pendirinya yang bernama Michael Timotius dan Jancent Ong yang berinisiatif membuat sebuah escape room yang tidak hanya sekedar memecahkan teka-teki, namun memberikan pengalaman dan interaksiyang dapat dirasakan pemain melalui komponen desain yang ada di dalam ruangan.

Pandora Lite merupakan wahana escape room yang berdurasi 1 jam dengan tingkat kesulitan dan interaksi yang rendah. Pandora Lite merupakan wahana escape room yang paling ringan untuk dinikmati. Pandora Lite berdurasi 1 jam dengan harga di hari kerja $R p$ 100.000 dan harga akhir minggu Rp 125.000. Lokasinya berada di Marvel City Mall, Ciputra Mall, dan Alam Sutera Mall.

Pandora Classic merupakan wahana escape room yang berdurasi 2 jam dengan tingkat kesulitan dan interaksi yang cukup tinggi, sehingga pemain lebih merasakan ketegangan dalam ruangan. Pandora Classic. Berdurasi 2 jam dengan harga di hari kerja Rp 180.000 dan harga akhir minggu Rp 200.000. Lokasinya berada di Puri Indah, Kelapa Gading, Marvell City Mall, Suka Jadi.

Pandora X-Series merupakan wahana escape room yang berdurasi 2 jam dengan tingkat kesulitan dan interaksi yang sangat tinggi. Di ruangan ini pemain akan benar-benar merasakan seperti bermain di dalam sebuah film. Dengan dukungan dari berbagai mekanisme dan plot twist dari episode Pandora X- Series. Pandora X-Series Berdurasi 2 jam dengan harga di hari kerja Rp 220.000 dan harga akhir minggu Rp 240.000. Lokasinya berada di Baywalk Mall, Kuta, dan Pakuwon Trade Center Supermall.
Jumlah konsumen Pandora Experience terbanyak adalah mahasiswa dengan umur 20-25 tahun, dengan kelas sosial A-B. Konsumen yang termasuk kategori ini memiliki ketertarikan dengan episode Pandora Experience yang memiliki tema Aksi dan Petualangan, salah satunya adalah Episode Alcatraz yang diminati dan dimainkan oleh 4/10 orang yang sudah diwawancara. Sedangkan orang yang tidak pernah main Pandora Experience ada 3/10 orang, namun mereka tahu apa itu Pandora Experience dan apa itu escape room. 1/10 orang pernah memainkan Pandora Experience, namun tidak tahu apa itu escape room.

\section{Identifikasi Tema Sama}

Perancangan ini memiliki persamaan terhadap sebuah permainan papan yang berjudul Exit : The Game, permainan ini merupakan sebuah permainan escape room dalam bentuk permainan papan dengan media utama kartu, dan media pendukung berupa spin roullete, yang dapat membantu untuk memecahkan teka-teki dalam game.

Perancangan ini berbeda dengan permainan Exit : TheGame dengan Unravel adalah media yang digunakan, tema ataupun cerita, dan tujuan dari permainan ini juga berbeda. Media yang digunakan Unravel adalah sebuah aplikasi dengan media tambahan berupa kartu. Tujuan dibuatnya game ini adalah untuk mempromosikan Pandora Experience sebagai wahana escape room nomor 1 di Indonesia. Tema dan cerita yang diambil tentu sangat berbeda game Exit: The Game menggunakan cerita yang original dibuatnya, sedangkan Unravel mengambil cerita dari Pandora Experience yang berasal dari sebuah legenda di beberapa negara dan mengubahnya menjadi sebuah cerita orisinil milik Pandora Experience dengan memiliki berbagai $p l o t$ twist didalamnya.

\section{Kesimpulan Analisis Data}

Dari kelemahan dan ancaman pada perusahaan Pandora Experience, dapat diatasi dengan menggaet target market yang belum mengenal Pandora Experience dan belum mengetahui arti dari wahana escape room, melalui beberapa media interaktif yang memberikan interaksi secara langsung. Karena Pandora Experience memiliki produk yang sangat bagus dan berkualitas, dan hanya perlu jembatan dalam bentuk promosi agar dapat sampai ke hati konsumen. 


\section{Perancangan}

\section{Tujuan Kreatif}

Tujuan dari pemasaran produk adalah untuk mengenalkan lebih dalam pengertian dari wahana escape room agar konsumen mampu merasakansensasi bermain escape room tanpa harus masuk ataupun spoiler cerita dari escape room tersebut. Tujuan lainnya adalah meningkatkan kualitas marketing mix yang terdiri dari produk, harga, tempat,dan promosi, agar dapat memenuhi target penjualan Pandora Experience. Serta menggaet target market yang sudah mengenal Pandora Experience namun belum pernah mencoba wahana escape room.

Tujuan penggunaan aplikasi adalah sebagai sarana pengenalan dalam jangkauan kecil. Namun dapat memudahkan konsumen dalam mempelajari dan merasakan wahana escape room Pandora Experience dalam bentuk media Interaktif berupa aplikasi dan media cetak kartu, yang berisikan clue untuk memecahkan teka teki yang ada dalam aplikasi escaperoom.

\section{Strategi Kreatif}

Perancangan ini menargetkan calon konsumen yang berumur 20-25 tahun dan termasuk kalangan menengah atas yang menyukai hiburan berupa permainan yang memiliki unsur audio visual, atau bisa disebut sebagai video game. Agar dapat memberikan interaksi antara konsumen dengan media ini.

Perusahaan tidaklah cukup hanya menciptakan produk berupa wahana escape room yang berkualitas terbaik dan membuat produk tersedia bagi pelanggan. Perusahaan juga perlu mengkomunikasikan produk dan perusahaan kepada pelangganya.

Pesan yang ingin disampaikan terhadap calon konsumen adalah berupa pengertian, makna, dan sensasi dari wahana escape room. Sehingga calon konsumen dapat mengerti arti dari escape room dan memiliki keinginan untuk mencoba memainkan wahana escape room di Pandora Experience. Pesan yang akan ditujukan secara garis besar meliputi kriteria dengan gaya bahasa dunia audio visual, tema yang diambil merupakan tema yang sudah populer dalam Pandora Experience seperti sci-fi dan misteri. font yang digunakan disesuaikan dengan tema dalam escape room yang akan dimasukan ke aplikasi.
Ada dua macam bentuk komunikasi yang biasa dipakai sebagai alat media penyampaian pesan, yaitu pesan verbal lebih dikenal dengan pesan tertulis yang disampaikan lewat kata atau tulisan. Pesan verbal yang akan disampaikan adalah kata-kata yang dapat memberikan suasana ataupun sensasi seakan-akan calon konsumen masuk kedalam sebuah cerita, dengan cara menjadikan calon konsumen adalah karakter utama dalam permainan tersebut. Pesan visual yang ada berupa gambar-gambar ataupun foto-foto yang dapat mendukung cerita dari episode escape room yang diangkat. Foto ataupun gambar yang ditampilkan merupakan desain gambar yang menyerupai komponen dalam escape room, dan berisikan sebuah clue untuk memecahkan teka teki dalam aplikasi.

\section{Program Kreatif}

Nama aplikasi yang diberikan adalah "Unravel" berasal dari kata ravel yang arti lainnya adalah puzzle. Unravel memiliki arti menguraikan, membuka seluk-beluk, ataupun menyelesaikan kekusutan.

Struktur desain dalam aplikasi akan berupa Sebuah halaman yang didalamnya berisi beberapa lapisan halaman. Halaman pertama akan berisi judul Aplikasi dan nama Perusahaan. Halaman kedua adalah pemilihan episode escape room, setelah memilih episode maka akan masuk langsung kedalam permainan dengan adanya beberapa indikator berupa timer, hint, code, machine, start/pause.

Dalam aplikasi memiliki alur desain interaktif yang mengarahkan pemain untuk klik aplikasi Unravel by Pandora Experience untuk membuka aplikasi. Setelah masuk ke aplikasi akan ada animasi nama aplikasi dan nama perusahaan, lalu lanjut ke pemilihan episode escape room yang hendak dipilih. Setelah masuk ke dalam permainan, pemain diberikan petunjuk untuk menekan tombol start untuk memulai permainan, dan mulai untuk memecahkan beberapa teka teki yang ada, dengan memanfaatkan media bantuan berupa kartu untuk mencari clue yang ada, serta mencari clue di dalam indikator machine. Setelah mendapatkan clue, pemain akan memasukan clue tersebut kedalam indikator code dan permainan akan selesai. Permainanselesai dan akan muncul video prolog dari episode tersebut, dilanjutkan dengan pesan advertorial 
diakhir permainan.

Terdapat unsur-unsur interaktif dalam aplikasi Unravel seperti :

1. Gaya bahasa yang digunakan adalah bahasa yang cukup rumit untuk dipahami untuk memberikan tantangan terhadap pemain dalam berpikir, untuk menyelesaikan permainan.

2. Gambar dan foto yang digunakan adalah gambar dan foto yang memberikan suasana mencekam dan misterius. Fungsinya agar pemain lebih merasa tertantang dan merasa berada di dalam wahan escape room sesungguhnya.

3. Audio yang digunakan adalah musik dengan instrument tanpa nyanyian, agar tidak mengalihkan perhatian pemain namun tetap menjaga agar tidak membosankan.

4. Video yang ditampilkan merupakan video yang berasal dari ilustrasi yang divideo kan, dengan tambahan suara dialog dan cerita prolog dari Pandora Experience.

5. Sistem navigasi tidak berupa tutorial, karena akan membosankan bagi pemain untuk melakukan tutorial dahulu. Sistem navigasi yang digunakan lebih ke pembuatan desain yang memberikan anomaly. Sehingga memudahkan pemain untuk menekan tombolselanjutnya.

\section{Konsep Visual Interface Desain}

Tone warna yang digunakan adalah warnawarna gelap dan mencekam yang disesuaikan dengan tema dari permainan escape room.

Karakter tipografi disesuaikan dengan cerita dan tema dari escape room yang akan dimasukan ke aplikasi Unravel. Jenis Tipografi yang digunakan adalah dekoratif yang tetap mudah dibaca dan dapat memberikan efek mencekam ke pemain. Oleh karena itu font yang digunakan adalah jenis font decoratif dengan tema misteri ataupun horor. Nama font yang digunakan adalah Octin Vintage, Boycott, Traveling Typewriter.

Dalam perancangan media interaktif ini akan dilakukan dengan pendekatan gaya desain vintage yang memberikan kesan mencekam. Karena warna-warna yang digunakan cenderung warna-warna gelap dan bentuk-bentuk yang realis.

Gaya visual ilustrasi yang dipakai akan terkesan realis, mencekam, misterius, dan menarik. Style yang diangkat sama dengan brand
Pandora Experience selama ini.

Gaya layout yang dipakai dalam media interaktif ini adalah Static disebut juga sebagai "layout fixed" karena menggunakan ukuran halaman yang sudah ditetapkan dan tidak merubah ukuran lebar aplikasi.

\section{Penjaringan Ide}

Puzzlel teka-teki aplikasi Unravel dibuat sesuai dengan standard dari Pandora Experience dan dengan beberapa teka - teki yang di ambil dari episode N.E.V.E.R.L.A.N.D namun ada juga teka-teki dengan jenis yang baru dengan tingkat kesusahan yang medium. Unravel juga di desain sesuai dengan escape room yang ada di Pandora Experience sehingga Unravel dapat memberikan pengalaman terhadap target audiens yang dapat memacu adrenalin, serta dapat menyesuikan brand nya dengan Pandora Experience. Media Interaktif Unravel dapat diselesaikan dengan waktu kurang lebih 10 menit, hal ini dikarenakan media interaktif yang ditunjukan untuk promosi, tidak boleh membiarkan konsumendan calon konsumen menunggu terlalu lama untuk memainkan media interaktif Unravel.

\section{Hasil Final}
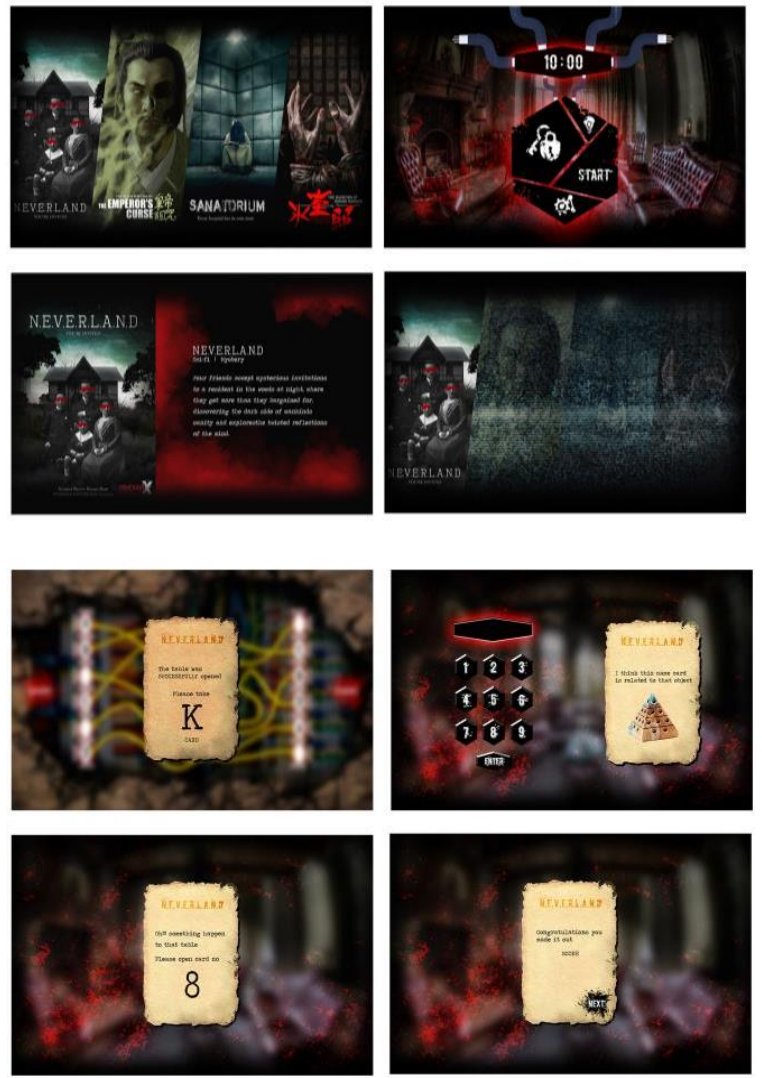

Gambar 2. Hasil Akhir Aplikasi 

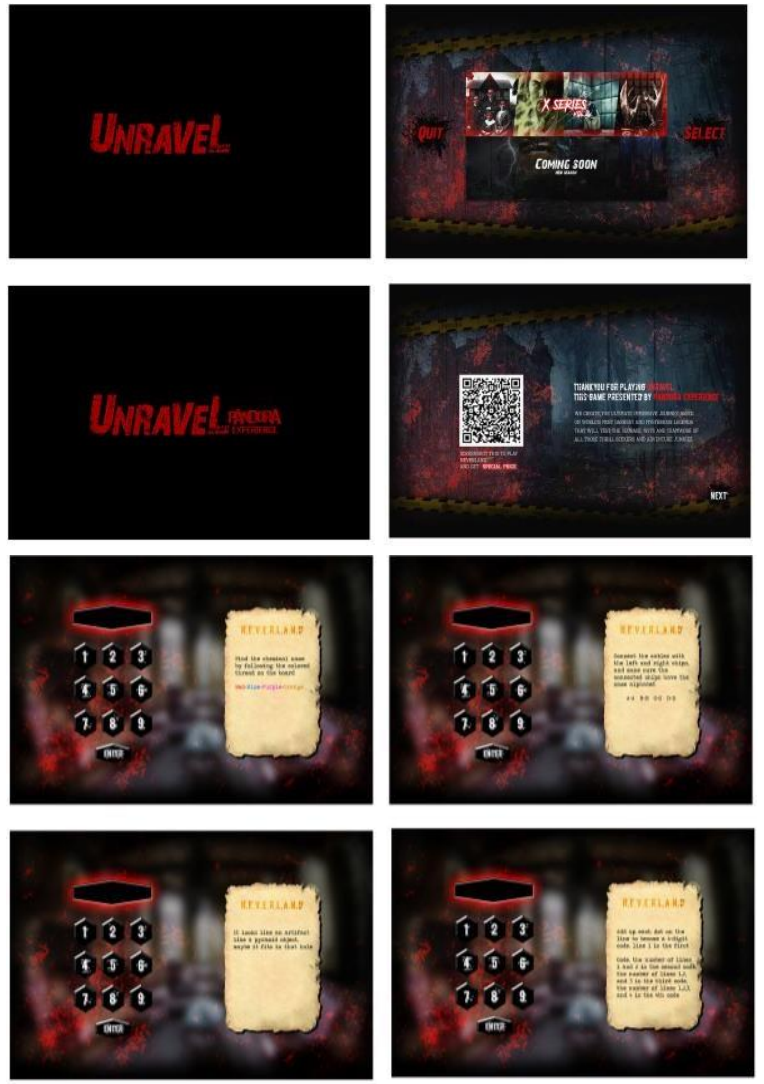

Gambar 3. Hasil Akhir Aplikasi
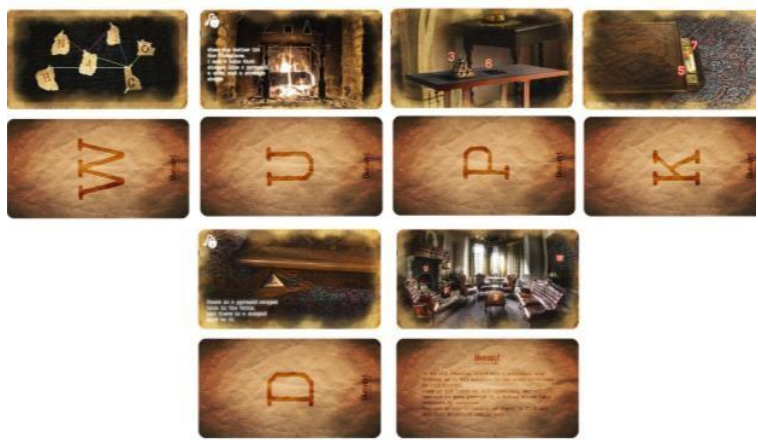

Gambar 4. Hasil Akhir Media Tambahan, Kartu Huruf
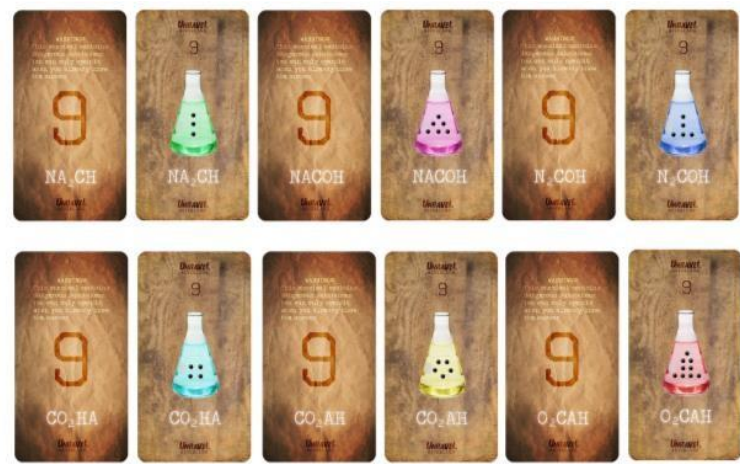

Gambar 5. Hasil Akhir Media Tambahan, Kartu Angka
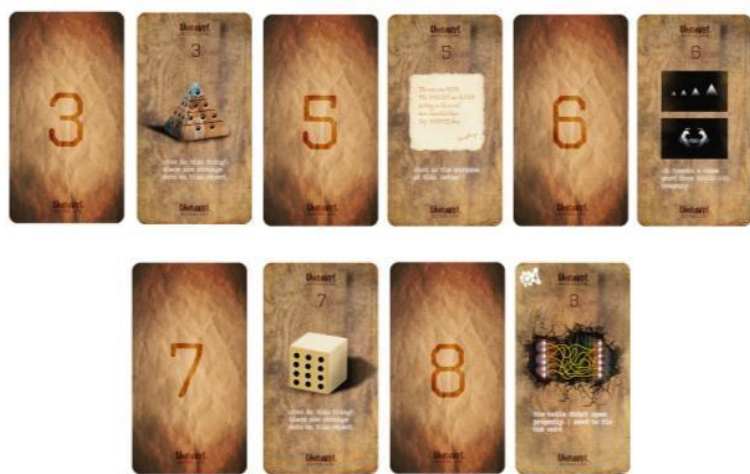

Gambar 6. Hasil Akhir Media Tambahan, Kartu Huruf

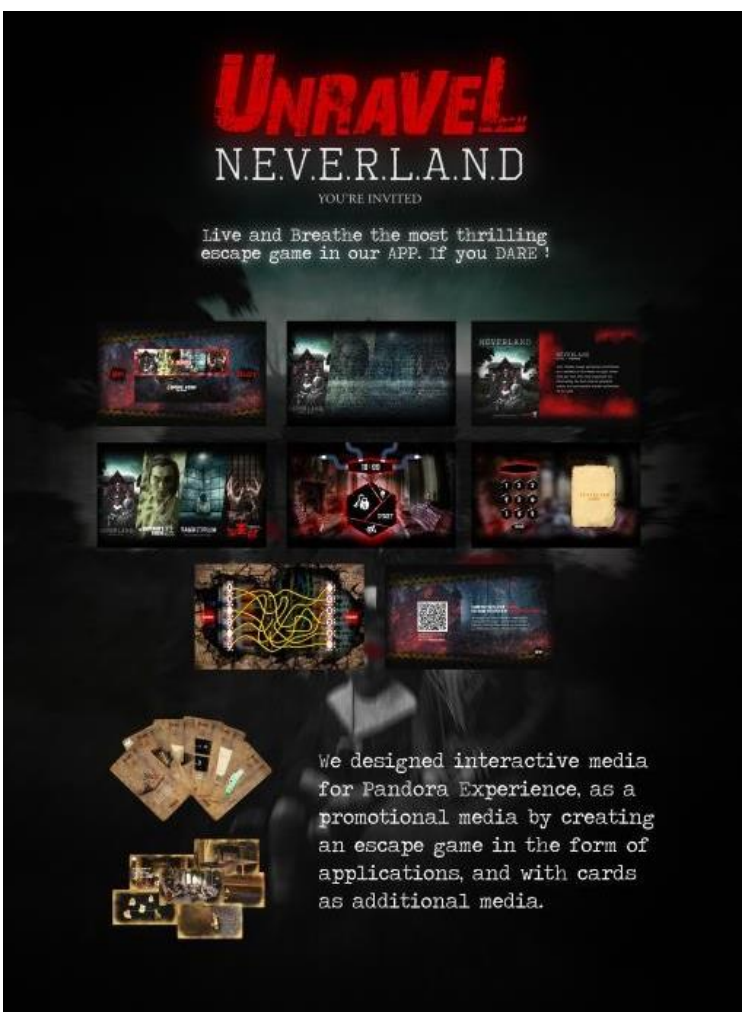

Gambar 7. Poster Unravel

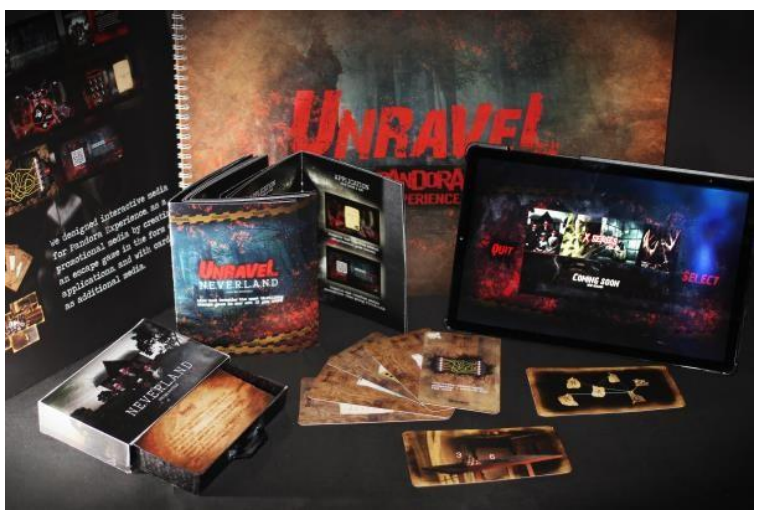

Gambar 8. Pengaplikasian di booth Pandora Experience Surabaya 


\section{Simpulan}

Minimnya pengetahuan masyarakat mengenai wahana escape room Pandora Experience yang ada di Surabaya sehingga pihak Pandora Experience mengalami sedikit kesulitan dikarenakan target market Pandora Experience yang merupakan $10 \%$ dari masyarakat Indonesia hanya berhasil mencapai $1.2 \%$ orang yang pernah bermain Pandora Experience.

Permasalahan yang ada ini dapat dijawab dengan desain. Dengan merancang sebuah alat media interaktif yang sesuai dengan minat target audiens saat ini, yaitu segala sesuatu yang bersifat digital dan interaktif, maka dirancanglah sebuah aplikasi interaktif sebagai trial bagi calon konsumen yang seluruh episode dan temanya berasal dari Pandora Experience. Dengan media interaktif ini diharapkan dapat memberikan pengalaman escape room bagi calon konsumen, serta menaikkan jumlah konsumen Pandora Experience.

Perancangan media interaktif ini telah di uji coba terhadap target audiens, dan mendapatkan respon yang baik. Mahasiswa dan pekerja yang menjadi target audiens terlihat sangat antusias dan mau mencoba, meski pada awalnya target audiens kesulitan untuk memecahkan teka-teki dari aplikasi ini, tetapi setelah mencoba sambil diberikan arahan bermain, target audiens mulai mengerti dan dapat memainkan aplikasi ini secaara lancar, dan sangat baik. Dengan adanya perancangan ini target audiens dapat mengerti apa itu escape room dan bagi Pandora Experience dapat menaikkan jumlah konsumennya.

\section{Daftar Pustaka}

Dhir, R. (2019,). Business: Investopedia. Retrieved: https://www.investopedia.com/terms/i/inter active-media.asp.

Morissan, M. (2010). Periklanan. Jakarta: Kencana.

Muqorobin, S. (2014). Perancangan Media Promosi dan Informasi Berbasis Multimedia Interaktif pada CV. Karunia Semarang. Pengertian Media Promosi, 1-15.

Sari, R. K. (2019). Strategi Kreatif Menulis Advertorial. Jurnal Abdimas BSI, 306-315.

Setiawan, E. B., \& Ramdany, A. T. (2012). Membangun Aplikasi Android, Web, dan Web Service. Bandung: Informatika.

Timotius, M. (2019). Market Pandora Experience. (E. Hendrawan, Interviewer) 